\title{
THE RISK-ADJUSTED PERFORMANCE OF COMPANIES WITH FEMALE DIRECTORS: A South AFrican CASE
}

\author{
Pumela Msweli-Mbanga \\ School of Management Studies, University of KwaZulu-Natal \\ Henry Mkhize \\ School of Economics and Finance, University of KwaZulu-Natal
}

\begin{abstract}
The objective of this research was to examine the effects of female directors on the risk-adjusted performance of firms listed on the JSE Securities Exchange of South Africa (the JSE). The theoretical underpinning for the relationship between representation of female directors and the risk-adjusted performance of companies was based on institutional theory. The hypothesis that there is no difference between the risk-adjusted performance of companies with female directors and that of companies without female directors was rejected. Implications of the results are discussed and suggestions for future research presented.
\end{abstract}

JEL J16

1

Introduction

According to institutional theory, organisations are defined and shaped by the institutional environment in which they are embedded (DiMaggio \& Powell, 1991). Accordingly, legal reform efforts and the introduction of Affirmative Action legislation in South Africa have resulted in an influx of women in the labour force. Research is now acknowledging the importance of diversifying human resource structure regarding gender as a necessary requirement for optimising essential resources in organisations. Scholars are arguing that, if women remain an under-utilised talent pool, then national economic growth will be hampered in the long-term (Cutler \& Jackson, 2002). It has also been found that female executives add value to organisations by introducing female values like caring, an appreciation for teamwork, intuitive decision making and a sense of social responsibility (Claes, 1999). The objective of this paper is thus to determine the performance of JSE-listed companies with female directors on a risk-adjusted basis.

\section{2}

\section{Review of related literature}

Notwithstanding the increase of women in the workforce, there remains a great disparity between the number of women in corporate leadership and the overall female working population. A survey conducted in 2004 by the Business Women's Association (BWA) showed that, of the 52 per cent of working women in South Africa, only 7.1 per cent were directors in the JSE-listed companies. The survey revealed further that women comprised only 3.0 per cent of chairs of boards and 1.9 per cent of chief executive officers (CEOs). Although there are no institutional explanations for the limited representation of women in senior management, a number of scholars have attributed this to the "glass ceiling" effect.

The term "glass ceiling" was first used in a 1986 Wall Street Journal article, with reference to the invisible barriers impeding the career advancement of women in the American workforce (Baker \& Lightle, 2001). The term has been further defined as the actual or perceived barrier, or cap, beyond which few 
women in public and private organisational structures are able to progress (Tavakolian, 1993). In the United States (US), the Federal Glass Ceiling Commission's report summarised the major barriers to women's advancement in organisations as placement in relatively dead-end staff jobs and lack of mentoring, management training and career development, as well as an absence of critical development activities (McDonald \& Hite, 1998).

Crampton \& Mishra (1999) identify a range of complex reasons explaining why there are fewer women in senior management positions in the US. These reasons include, amongst others, socialisation patterns, choice of positions that lack power or supervisory authority, fulfilling the dual roles of working woman and mother, and the lack of confidence, appropriate skills and attitudes needed for women to succeed as managers. In another study, Nelson and Burke (2000) report that male CEOs view the obstacles to women's corporate progress as being their lack of general management skills, spending insufficient time in the pipeline, male stereotyping and preconceptions of women, exclusion from informal networks and an inhospitable corporate culture.

While there are obviously many explanations for the barriers to women's career advancement, Nelson and Burke (2000) identify two as being particularly plausible: (1) subtle forms of discrimination that increase the probability of women's failure, namely inadequate provision of development opportunities and unwillingness on the part of those in power to confront and eliminate sexism; (2) the fact that women are afforded different development opportunities from those enjoyed by men. The authors point out that, in particular, mentoring is not adequately provided for women, on account of the limited numbers of women in top management.

Institutional theory, on the other hand, suggests that the glass ceiling is perpetuated by cultural biases, which define leadership competence in terms of male characteristics and traits (Frankforter, 1996). Researchers have also suggested that male organisational culture explains the persistence of the glass ceiling effect (Van Vianen \& Fischer, 2002;
Cassell \& Walsh, 1997; Maddock, 1999). Shakeshaft (1987) emphasises this argument by pointing out that male dominance in key social positions and the prevalence of patriarchal norms reinforcing gender differences constitute a serious impediment to women's career advancement. The implication is that, if a masculine culture prevails in an organisation, then the institutionalisation of a policy to appoint women to key management positions will be influenced by the men in that particular environment.

Indeed, researchers argue that institutionalisation of any policy generally depends on the relative power of 'critical constituencies' and interested actors who stand to gain from whether or not a policy is fully implemented (DiMaggio, 1988; Blair-Loy \& Wharton, 2002). For example, in a study conducted by Blair-Loy and Wharton (2002) investigating the institutionalisation of work-family policies, the 'critical constituencies' of these policies were women.

This study investigates the institutionalisation of the policy that includes women in the corporate leadership of companies listed on the JSE, for the period 2002-2003. It argues that appointing women to corporate director positions signifies those corporations' responsiveness to employment equity policy, and reasonably expects that the extent to which women are represented in their corporate leadership will affect their share price returns. The purpose of this study is to estimate riskadjusted returns of JSE-listed companies with female directors (WOMEN portfolio) and to compare them with:

- risk-adjusted returns of companies without women directors (NO-WOMEN portfolio).

- risk-adjusted returns of the overall market (MARKET portfolio).

A number of scholars (Claes, 1999; Appold, Siengthai \& Kasarda, 1998; Cutler \& Jackson, 2002) argue that women add value to an organisation by introducing female qualities like team spirit, caring, intuitive decisionmaking and corporate social responsibility. A positive impact by female directors on 
the performance of companies listed on the JSE is expected. This expectation is based on Arthur's (2003) study showing that policy adoption resulting in 'legitimation' has a positive effect on the value of a firm. Based on Arthur's conclusion, it could be inferred that the same policy adoption would result in superior performance as measured by the Sharpe Index. In this study, the 'legitimating process' refers to compliance with an employment equity policy, as illustrated by the representation of women in top management. It could therefore be expected that the higher the percentage of women directors in a company the better the company's financial performance, as measured by the Sharpe Index, to be discussed in the section on methodology below. The hypothesis this study seeks to test is that:

$\mathrm{H}_{0}$ : There is no difference between the performance of companies with women directors and the performance of companies without women directors.

$\mathrm{H}_{1}$ : There is a difference between the performance of companies with women directors and the performance of companies without women directors.

3

\section{Methodology}

Data

The Business Women's Association (BWA) gave permission for the writers to use the results of a 2004 nationwide census of female board directors for companies listed on the JSE. The BWA data set of 347 observations was the starting point for this research procedure. Only those companies listed on the JSE on 30 September 2003 were included in this data set. Using the BWA data set, data was computed with two variables: (1) companies with female directors, and (2) companies without female directors.

Share price data for the period October 2002September 2003 was obtained from McGregor (2004), who provides a comprehensive database of JSE-listed companies. Risk-free rates were obtained from the website of the South African
Reserve Bank. To eliminate bias due to different financial year-ends, only companies with a common year-end were selected, which reduced the sample size from 347 to 115 companies. Daily share price returns were computed over a 12-month period, from 1 October 2002-30 September 2003.

\subsection{Construction of WOMEN and NO- WOMEN portfolios}

Before an assessment of performance was conducted, companies were divided into two distinct groups:

- WOMEN (these were companies with women directors)

- NO-WOMEN (these were companies without women directors).

\subsection{Measuring performance}

According to Fabozzi (1999), performance assessment involves performance measurement and performance evaluation. Fabozzi (1999) defines performance measurement as the return realised over a certain time interval, called the evaluation period. He defines performance evaluation as the act of determining whether value was added by the out-performance of an established benchmark. The well-established benchmark used in this study was the All Share Index (ALSI), which is regarded as one of the generally-accepted market proxies in the Republic of South Africa. For the purpose of this study, this benchmark represents the MARKET portfolio.

Affleck-Graves, Burt and Cleasby (1988) and Van den Honert, Barr and Smale (1988) computed share price returns $\left(\mathrm{R}_{\mathrm{i}}\right)$, using the following formula:

$\mathrm{R}_{\mathrm{i}}=\frac{P_{1 i}-P_{0 i}}{P_{0 i}} \times 100$

Where: $\mathrm{P}_{1 \mathrm{i}}$ is the price of a share I/ALSI at the close of a trading day;

$\mathrm{P}_{0 \mathrm{i}}$ is the price of a share $\mathrm{I} / \mathrm{ALSI}$ at the opening of a trading day.

This formula was adopted in this study in order to compute daily portfolio and market returns. 
Daily returns of WOMEN, NO-WOMEN, and MARKET portfolios were thereafter averaged. These averaged daily returns for each of the portfolios were then annualised over the evaluation period.

In order to arrive at a risk-free rate, Banker's Acceptance (BA) discount rates were obtained from the website of the South African Reserve Bank. These were utilised to obtain the quoted price in order to compute a risk-free rate. These three-month quotes for BAs were obtained for:

- the first week of October 2002 (that is, to be redeemed at the end of December 2002);

- the first week of January 2003 (that is, to be redeemed at the end of March 2003);

- the first week of April 2003 (that is, to be redeemed at the end of June 2003);

- the first week of July 2003 (that is, to be redeemed at the end of September 2003).

Three-month yields were computed in compound factor form and then multiplied together in order to get an annualised return on a strategy entailing purchasing and holding a three-month BA until maturity, re-investing the proceeds in a second BA, and holding until maturity (a roll-over investment strategy). This rolling-over investment strategy was repeated until the end of the evaluation period at the end of September 2003.

Mayo (2005) maintains that the Sharpe and Treynor Indices are alternative measures of performance. Fabozzi (1999) argues that the Sharpe Index (SI) is a measure of the rewardto-risk ratio, and that the risk of the share is measured by the standard deviation of the share. Bodie, Kane and Marcus (2002) maintain that the attractive feature of the Sharpe Index is that it divides the average return over the relevant time period by the standard deviation of returns over that period, thereby measuring the rewardto-volatility trade-off. Bodie et al. (2002) contend that directors seek to maximise the Sharpe Index of their companies. It is argued in this research that companies maximise the Sharpe Index by recruiting, training and retaining female directors owing to the benefits associated with women in leadership. This transfers directly to the hypothesis that the performance of companies with female directors, as measured by the Sharpe Index, will be different from that of companies without female directors, also measured by the Sharpe Index. Companies will therefore partially maximise shareholders' wealth if they conform to institutional theory.

Mayo (2005) argues that the Sharpe Index is given as follows:

$\mathrm{SI}=\frac{R_{i}-R_{f}}{S D_{i}}$

Where: $R_{i}$ is the average return on WOMEN, NO-WOMEN or MARKET,

$\mathrm{R}_{\mathrm{f}}$ is the return on bankers' acceptance annualised rate (risk-free rate), and

$\mathrm{SD}_{\mathrm{i}}$ is the standard deviation of WOMEN, NO-WOMEN or MARKET portfolios.

It is further argued that the Sharpe Index is a measure of the excess of the risk-free return relative to the total variability of the company (Bodie et al., 2002). In this research, standard deviation, not beta, is the appropriate measure of a company's risk, because individual share price returns are used, not portfolio returns, which may be diversified.

The higher the Sharpe Index, the higher the past performance of the company. All companies should therefore aim to maximise the Sharpe Index. This research infers that the Sharpe Index will be higher if a company applies 'smart' recruitment policy by appointing women to senior management positions and, in turn, complying with the Employment Equity policy of the Republic of South Africa. The recruitment policy will be regarded as 'smart' if a company recruits, trains and retains a higher percentage of women than other comparable companies.

\section{4 \\ Results}

Standard deviations of WOMEN, NO-WOMEN and MARKET over the study period are presented in Table 1 below. Table 1 also shows the average returns of WOMEN, NO-WOMEN, MARKET and RISK-FREE variables. Sharpe Indices of all portfolios are also contained in Table 1. 


\section{Table 1}

Sharpe indices of all portfolios

\begin{tabular}{|l|c|c|c|}
\hline Variable name/portfolio & Standard deviation & Average return & $\begin{array}{c}\text { Sharpe index } \\
=\left(\mathbf{R}_{\mathbf{i}}-\mathbf{R}_{\mathbf{f}}\right) / \text { SD }\end{array}$ \\
\hline WOMEN & 1.25 & $14.02 \%$ & $0.35 \%$ \\
\hline NO-WOMEN & 0.79 & $25.62 \%$ & $15.19 \%$ \\
\hline MARKET & 1.19 & $-2.30 \%$ & $-13.37 \%$ \\
\hline RISK-FREE & not applicable & $13.59 \%$ & not applicable \\
\hline
\end{tabular}

The NO-WOMEN portfolio has the highest Sharpe Index. It out-performed both the WOMEN portfolio by 14.84 per cent and the MARKET portfolio by 28.56 per cent. The WOMEN portfolio out-performed the MARKET portfolio by 13.72 per cent. Overall, the NO-WOMEN portfolio achieved superior results during the evaluation period October 2002 - September 2003.

A t-test was conducted to compare the differences in the means between the performance of companies with female directors and that of companies with no female directors. Table 2 below provides the results of the test.

Table 2

t-test for comparison of means

\begin{tabular}{|l|l|c|c|c|}
\hline & \multicolumn{1}{|c|}{ t } & df & Sig (2-tailed) \\
\hline $\begin{array}{l}\text { Performance:women/no women } \\
\text { portfolios }\end{array}$ & $\begin{array}{l}\text { Equal variances } \\
\text { assumed }\end{array}$ & 2.18 & 98 & .031 \\
\hline
\end{tabular}

The null hypothesis that there is no difference between the performance of companies with women directors and that of companies without women directors is rejected. The p-value of .031 (in Table 2) represents the probability of error associated with rejecting the hypothesis that there is no difference between the performance of companies with female directors, and that of companies without female directors.

\section{5}

\section{Discussion and conclusions}

This study tested the effects of female directors on the risk-adjusted performance, as measured by the Sharpe Index, of companies listed on the JSE over a twelve-month period 2002-2003. The hypothesis that there is no difference between the performance of companies with female directors and the performance of companies without female directors was rejected. These findings indicate that there is a statistically significant difference between the two categories of companies. Findings contained in Table 1 (above) showed that the Sharp Index of a group of companies without female directors was higher than the Sharp index of a group of companies with female directors.

From the perspective of institutional theory, these findings imply that the adoption of a policy to appoint women to top management positions is not perceived to have a positive effect on the performance of these companies. A study conducted by Chevalier and Ellison (1999), although it differs from the present one in considering how cross-sectional performance is related to observable characteristics like the institution from which a manager received his/ her undergraduate degree, or whether she or he has an MBA degree, showed no clear evidence of the relationship between performance and women fund-manager characteristics. The lack of evidence was attributed to the fact that women comprised only 7 per cent of the sample examined. Chevalier and Ellison's study (1999) found instead that things like a 
better education, social networks and age were predictive of performance. A study by Golec (1996) also showed that age and the length of time a manager has managed his or her fund are the most significant predictors of portfolio performance.

From the perspective of institutional theory, the findings of this study could be interpreted as indicating that the core constituents of South African firms perceive the institutionalisation of the Employment Equity policy as having no effect on their individual bottom lines. The present findings also indicate that the Employment Equity Act was possibly adopted for symbolic rather than substantive reasons, which could explain the slow adoption rate of the policy. These findings are not consistent with those of Arthur (2003), which showed an increase in share price with the institutionalisation of a work-family policy. It could be argued that the way in which the investors (existing and potential shareholders as indicated by supply of and demand for shares) perceive the policy in terms of adding value determines the institutionalisation of the policy.

The findings show clearly that investors at the JSE do not see any additional value in recruiting, training and retaining female rather than male directors. It is also clear that investors are interested in the return of their investment, irrespective of the gender of those who handle their investment portfolios. In other words, it does not matter whether a shareholder's wealth, the supposedly ultimate goal of any manager, is being maximised by a man or a woman. A subject for future research could be that of investigating the underlying reasons for the disparity in the numbers of women and men in corporate leadership viewed from the investors' perspective. Such an investigation would throw some light on whether stereotypical beliefs about women have any bearing on investor perceptions. A critical mass of research is required to address the limited number of women in senior management positions. This is of the utmost importance in South Africa at the present time, considering the current focus on employment equity. Such research should identify barriers to the corporate progress of women in the country. Engaging women at all levels in the corporate, particularly in positions of corporate leadership, would not only have a substantive impact on the economy, but would also ensure optimal use of the country's human capital.

This study has several limitations. First, the effect of different industries was not controlled. Industries like retailing, for example, would probably have more women in top management than do the manufacturing and mining industries. Further research is needed to examine industry effects on the institutionalisation of employment equity policies. Secondly, the small size of the sample and the fact that the study was confined to JSE-listed companies limited the generalisation of the findings to other companies. Thirdly, studying the effects of the representation of women on share-price returns over a period of one year may have been an oversimplification. Fourthly, prior research on mergers and acquisitions at the JSE indicated that share prices are highly sensitive to a proposed merger (Affleck-Graves et al., 1988; Van Honert et al., 1988), and these effects on share-price returns were not isolated. Future researchers may want to exclude from their samples all companies that have been involved in mergers and acquisitions. Fifthly, and most important, Sharpe Indices used in this study can change dramatically, depending on the timeperiod of the analysis. Again, a longer-term period would be required to properly address this limitation. Further research, focusing on a number of performance variables, may provide a better understanding of the effect of women directors on firm performance.

Finally, in addition to the drawbacks of measuring short-term performance, the WOMEN and NO WOMEN portfolios were judged according to past performance. The rationale for doing so was that the portfolios that had, on average, under- or over-performed during the study period would continue to do so in the future. However, the efficient market hypothesis $(\mathrm{EMH})$ provides no support for the use of past performance as a predictor of future performance. Whether the above-mentioned rationale is correct or not will depend on the level of market efficiency of the JSE. 


\section{References}

1 AFFLECK-GRAVES, J.F.; BURT, G.H. \& CLEASBY, S.J.M. (1988) "The premium on acquisition in South African mergers: An empirical evaluation", South African Journal of Business Management, 19(4): 55-160.

2 APPOLD, SJ.; SIENGTHAI, S. \& KASARDA, J.D. (1998) "The employment of women managers and professionals in an emerging economy: Gender inequality as an organizational practice", Administrative Science Quarterly, 45: 538-565.

3 ARTHUR, M.M. (2003) "Share price reactions to work-family initiatives: An institutional perspective, Academy of Management Journal, 46 (4): 497.

4 BAKER, B. \& LIGHTLE, S.S. (2001) "Cracks in the glass ceiling: An analysis of gender equity in the federal government auditing career field", The Journal of Government Financial Management, 50(3): 18-26.

5 BLAIR-LOY, M. \& WHARTON, M. (2002) "Employees' use of work -family policies and the workplace social context", Social Forces, 80(3).

6 BODIE, Z.; KANE, A. \& MARCUS, A.J. (2002) Investments (int. ed.) McGraw-Hill: Irwin.

7 BUSINESS WOMEN ASSOCIATION CENSUS (2004) South African Women in Corporate Leadership.

8 CASSELL, C. \& WALSH, S. (1997) "Organisational cultures, gender management strategies and women's experience of work", Feminism \& Psychology, 7: 224-230.

9 CHEVALIER, J. \& ELLISON, G. (1999) "Are some mutual fund managers better than others? Cross-sectional patterns in behaviour and performance", The Journal of Finance, LIV(3): 875-899.

10 CLAES, M. (1999) "Women, men, and management styles", International Labour Review, 138(4): 431-446.

11 CUTLER, M.M. \& JACKSON, A.L. (2002) "A 'glass ceiling' or work/family conflict?” The Journal of Business and Economics Studies, 8 (2): 73-85.

12 CRAMPTON, S.M. \& MISHRA, J.M. (1999) "Women in management", Public Personnel Management, 28.

13 DiMAGGIO, P. (1988) "Interest and agency in institutional theory", Institutional Patterns and Organizations: 3-22.

14 DiMAggiO, P.J. \& POWELL, W.W. (1991) The New Institutionalism in Organizational Analysis, University of Chicago Press: Chicago.

15 FABOZZI, (1999) Investment Management (2 $\left.{ }^{\text {nd }} e d.\right)$ Prentice-Hall: New Jersey.
16 FRANKFORTER, S.A. (1996) "The progression of women beyond the glass ceiling”, Journal of Social Behaviour \& Personality, 11(5).

17 GOLEC, J.H. (1996) "The effects of mutual fund managers' characteristics on their portfolio performance, risk and fees", Financial Services Review (5): 133-148.

18 MADDOCK, S. (1999) Challenging Women: Gender, Culture And Organisation, Sage, London.

19 MAYO, H.B. (2005) Investments: An Introduction ( $8^{\text {th }}$ ed.) Thomson: South-Western.

20 McDONALD, K.S. \& HITE, L.M. (1998) "Exploring the glass ceiling: An exploration of gender differences in management-development experiences", Journal of Management Education, 22(2): 242-254.

21 McGREgOR, (2004) Who Owns Whom in South Africa? (24 $4^{\text {th }}$ ed.) Carla Soares: Johannesburg.

22 NELSON, D.L. \& Burke, R.J. (2000) "Women executives: Health, stress, and success", Academy of Management Executive, 14(2): 107-121.

23 SHAKESHAFT, C. (1987) Women in Educational Administration, Sage: Newbury Park.

24 TAVAKOLIAN, H.R. (1993) "Break on through to the other side of the glass ceiling", Equal Opportunities International, 12(6): 14.

25 VAN DEN HONERT, R.C.; BARR, G.D.I., AFFLECK-GRAVES, J.F. \& SMALE, G. (1988) "Merger announcements and share price return - The role of the relationship between acquiring and target firms", South African Journal of Business Management, 19(1): 1-10.

26 VAN VIANEN, A.E. \& FISCHER, A.H. (2002) "Illuminating the glass ceiling: The role of organizational culture", Journal of Occupational and Organizational Psychology, 75(3): 315.

27 ZANE, N.C. (2002) "The glass ceiling is a floor my boss walks on: Leadership challenges in managing diversity", The Journal of Applied Behavioral Science, 38 (3): 443-354. 